\title{
Pengaruh Partisipasi Anggaran, dan Sistem Pengendalian Intern Pemerintah dengan Komitmen Organisasi Sebagai Variabel Moderasi Terhadap Kinerja Manajerial pada Organisasi Perangkat Daerah (OPD) Di Provinsi Jambi
}

\author{
Syindy Cantika, Mukhzarudfa, Gandy Wahyu Maulana Zulma* \\ Universitas Jambi, Indonesia \\ *Correspondence email: maulanagandi25@unja.ac.id
}

\begin{abstract}
Abstrak. Penelitian ini meneliti pengaruh partisipasi anggaran, sistem pengendalian intern pemerintah dengan komitmen organisasi sebagai variabel moderasi terhadap kinerja manajerial. Tujuan penelitian ini untuk mengetahui pengaruh dari variabel diatas baik pengaruh parsial maupun moderasi. Populasi penelitian ini adalah seluruh pegawai Organisasi Perangkat Daerah (OPD) urusan pemerintahan wajib yang berkaitan dengan pelayanan dasar. Teknik pengambilan sampel menggunakan purposive sampling. Dari lima OPD yang masuk ke dalam urusan pemerintah wajib yang berkaitan dengan pelayanan dasar sebanyak 120 orang pegawai sebagai responden dalam penelitian ini. Metode yang digunakan dalam penelitian ini ialah analisis regresi linie berganda dan moderated regression analisys (MRA). Software yang digunakan untuk mengolah data pada penelitian ini ialah SPSS versi 25. Hasil dari penelitian ini partisipasi anggaran berpengaruh positif dan signifikan terhadap kinerja manajerial, sistem pengendalian intern pemerintah berpengaruh positif dan signifikan terhadap kinerja manajerial, komitmen organisasi tidak mampu memperkuat pengaruh partisipasi anggaran terhadap kinerja manajerial, dan komitmen organisasi tidak mampu memperkuat pengaruh sistem pengendalian intern pemerintah terhadap kinerja manajerial.
\end{abstract}

Kata kunci: Kinerja Manjerial; Komitmen Organisasi; Partisipasi Anggaran; Sistem Pengendalian Intern

\begin{abstract}
This study examines the effect of budgetary participation, government internal control systems with organizational commitment as a moderating variable on managerial performance. The purpose of this study was to determine the effect of the above variables, either partial or moderation. The population of this study were all employees of the Regional Apparatus Organization (OPD) of mandatory government affairs related to basic services. The sampling technique used purposive sampling. Of the five OPDs that are included in mandatory government affairs related to basic services, there are 120 employees as respondents in this study. The method used in this research is multiple linear regression analysis and moderated regression analysis (MRA). The software used to process data in this study is SPSS version 25. The results of this study that budget participation has a positive and significant effect on managerial performance, government internal control systems have a positive and significant effect on managerial performance, organizational commitment is unable to strengthen the effect of budget participation on performance. Managerial, and organizational commitment is not able to strengthen the influence of the government internal control system on managerial performance.
\end{abstract}

Keywords: Budget Participation; Government Internal Control System; Managerial Performance; Organizational Commitment

\section{PENDAHULUAN}

Penelitian ini penting karena membahas mengenai kinerja manajerial pemerintahan daerah, dimana semakin baiknya kinerja manajerial pemerintah daerah khususnya di Provinsi Jambi maka akan semakin baik juga pelayanan terhadap kepentingan masyarakat di Provinsi Jambi.

Undang-undang tentang Pemerintah Daerah dan Undang-undang tentang Perimbangan Keuangan Pusat dan Daerah yaitu Undang-undang 32 dan 33 tahun 2004 membuat pemerintah daerah harus melakukan desentralisasi atau melimpahkan kewenangan pusat ke daerah. Kewenangan ini membuat pemerintah daerah harus membuat sebuah visi, misi, dan tujuan daerah masing-masing untuk menjadi tolak ukur demi membuat pencapaian yang baik dan terwujudnya kesejahteraan masyarakat daerah. Dalam organisasi pencapaian disebut kinerja manajerial (Bastian, 2010).
Adanya kinerja manajerial yang baik tentunya tidak terlepas dari faktor-faktor pendukung yang membuat hal itu bisa terjadi. Dalam penelitian ini terdapat tiga faktor yang diteliti yang diduga mampu mempengaruhi kinerja manajerial baik secara parsial maupun moderasi yaitu partisipasi anggaran, sistem pengendalian intern pemerintah dan komitmen organisasi.

Kinerja manajerial adalah pencapaian yang dicapai oleh individu atau kelompok dalam sebuah organisasi atas dijalankannya kegiatan-kegiatan manajerial yaitu perencanaan, investigasi, pengkoordinasian, evaluasi, pengawasan, pengaturan staf, negosiasi, dan perwakilan atau representasi demi tercapainya tujuan organisasi (Harefa, 2008). Memberikan pelayanan publik bukan memaksimalkan laba merupakan tujuan utama dari sektor publik atau pemerintahan (Bastian, 2010). Dua variabel bebas dalam 
Syindy Cantika, Mukhzarudfa dan Gandy Wahyu Maulana Zulma, Pengaruh Partisipasi Anggaran, dan Sistem Pengendalian Intern Pemerintah dengan Komitmen Organisasi Sebagai Variabel Moderasi Terhadap Kinerja Manajerial pada Organisasi Perangkat Daerah (OPD) Di Provinsi Jambi

penelitian ini ialah variabel partisipasi anggaran dan sistem pengendalian intern pemerintah, dan selanjutnya terdapat variabel moderasi berupa komitmen organisasi.

Partisipasi anggaran adalah terdapatnya kesempatan berkomunikasi antara kepala bagian dan staf-stafnya dalam penyusunan anggaran (Usman, 2017). Anggaran memegang peranan penting sebagai alat untuk mengontrol jalannya organisasi, sehingga strategi yang ditetapkan dapat digunakan untuk mencapai tujuan organisasi (Triana, et al., 2012) dan tujuan yang disusun secara bersama atau partisipasi anggaran akan memunculkan rasa tanggungjawab dari masing-masing individu untuk melakukan kinerja yang lebih baik. Partisipasi anggaran mempengaruhi kinerja manajerial didukung oleh penelitian Setiawan dan Rohani, (2019), Bumulo, et al., (2019), dan Usman, (2017).

Kebijakan dan prosedur yang dirancang untuk memberikan manajemen kepastian yang layak bahwa organisasi telah mencapai tujuan dan sasarannya disebut sistem pengendalian intern. Peraturan Pemerintah No.8 Tahun 2006 menyatakan bahwa kinerja manajerial akan meningkat apabila tujuan dan sasaran organisasi telah tercapai. Sistem pengendalian intern pemerintah berpengaruh terhadap kinerja manajerial didukung oleh penelitian yang dilakukan oleh Candrakusuma dan Jatmiko, (2017), Jannah dan Rahayu, (2015), dan Putri, (2013).

Kepercayaan dan dukungan yang kuat untuk nilai dan sasaran (goal) yang ditargetkan oleh organisai sering dikenal sebagai komitmen organisasi (Mowday et.al., 1982). Mengikut sertakan individu yang nilai-nilainya tidak sejalan dengan organisasi yang ada akan menghasilkan karyawan yang cenderung kurang mempunyai motivasi dan komitmen (Sumarno, 2006).

Fenomena yang terjadi di Provinsi Jambi mengenai capaian kinerja yang tertuang di Laporan Kinerja Jambi tahun 2019, Provinsi Jambi melalui Indikator Kinerja Utama (IKU) yang terukur dari 15 indikator rata-rata pencapaian sangat baik, tetapi masih ada pencapaian yang belum maksimal dan bahkan rendah, oleh karena itu pembenahan dan kelanjutan atas evaluasi harus dilakukan guna untuk memperbaiki kinerja di tahun-tahun berikutnya. Beberapa Penyebab dari belum maksimalnya pencapaian ialah kurangnya partisipasi anggaran sehingga terjadi asimetri informasi, kurangnya sistem pengendalian sehingga target yang ingin dicapai masih belum maksimal, dan beberapa penyebab lainnya.

Penelitian ini dilakukan di Organisasi Perangkat Daerah (OPD) Provinsi Jambi pada bagian pemerintahan urusan wajib yang berkaiatan dengan pelayanan dasar, menurut UU 23 tahun 2014 Urusan Pemerintahan Wajib yang berkaitan dengan Pelayanan Dasar ialah pendidikan, kesehatan, pekerjaan umum dan penataan ruang, perumahan rakyat dan kawasan permukiman, ketenteraman, ketertiban umum, \& pelindungan masyarakat, dan Sosial. terdiri atas lima OPD.

Alasan memilih lima OPD tersebut karena empat dari lima elemen pelayanan dasar ini merupakan pelayanan yang pada orde pemerintahan manapun akan sangat dibutuhkan dan sangat dekat dengan masyarakat yaitu pendidikan, kesehatan, keamanan, dan sosial untuk elemen pekerjaan umum karena pada pemerintahan sekarang ini sektor infrastruktur sedang diunggulkan untuk ditingkatkan kinerjanya. Terlebih dalam keadaan pandemi seperti sekarang ini lima pelayanan dasar itu lah yang paling membantu dan paling berperan kepada masyarakat. Untuk kinerja yang maksimal kita tahu bahwa ada faktor-faktor yang akan mempengaruhi setiap kinerja elemen tersebut.

Kontribusi dari penelitian ini ialah, pertama penelitian ini menggabungkan beberapa indikator kuesioner dari beberapa penelitian sehingga tingkat kesesuaian hasil dengan keadaan sebenarnya akan semakin tinggi karena terdiri dari beberapa sumber yang saling melengkapi untuk ditanyakan, kedua penelitian ini akan membahas mengenai penyebab inkonsistensi atau penyebab variabel partsipasi anggaran tidak berpengaruh terhadap kinerja manajerial pada literatur-literatur sebelumnya.

\section{METODE \\ Teori Keagenan, Teori Motivasi, dan Teori Penetapan Tujuan}

Teori keagenan dalam pemerintahan digambarkan, pemerintah (agent) diberikan amanah oleh masyarakat (principal) untuk menyelenggarakan kegiatan pemerintahan yang baik dan transparan, namun dalam hal ini kepala-kepala dalam pemerintahan membutuhkan koordinasi dengan bawahan agar tujuan dapat tercapai salah satu bentuk koordinasi itu ialah dengan mengikut sertakan bawahan dalam penyusunan anggaran, dalam rangka mewujudkan kesejahteraan masyarakat (Medina, 2012).

Teori motivasi menjelaskan bahwa ada dua alasan utama mengapa penganggaran partisipatif diperlukan Brownell, (1986) dalam Sumarno, (2006) yaitu, terjadinya pengendalian informasi yang tidak simetris dan ketidakpastian tugas karena adanya keterlibatan bawahan dan juga atasan dalam penganggaran partisipatif, melalui penganggaran partisipatif dapat mengurangi tekanan dalam tugas dan mendapatkan kepuasan kerja, selanjutnya dapat meningkatkan kinerjanya.

Latham and Locke (2006) pada teori penetapan tujuan menemukan bahwa kinerja karyawan dalam organisasi publik dapat dipengaruhi oleh penetapan tujuan dalam organisasi. Bentuk nyata dari implementasi teori penetapan tujuan ini ialah anggaran. Latham and Locke (2006) menjelaskan bahwa goal setting theory merupakan salah satu bagian dari teori motivasi 
Syindy Cantika, Mukhzarudfa dan Gandy Wahyu Maulana Zulma, Pengaruh Partisipasi Anggaran, dan Sistem Pengendalian Intern Pemerintah dengan Komitmen Organisasi Sebagai Variabel Moderasi Terhadap Kinerja Manajerial pada Organisasi Perangkat Daerah (OPD) Di Provinsi Jambi

menjelaskan bahwa seseorang akan bergerak jika memiliki tujuan yang jelas dan pasti.

\section{Partisipasi Anggaran}

Nafarin, (2004) menginterpretasikan bahwa berdasarkan program yang telah disahkan tersusunlah suatu rencana keuangan periodik yang disebut sebagai anggaran . Anggaran bersifat formal dan sistematis untuk pelaksanaan tanggung jawab manajemen didalam perencanaan, koordinasi dan pengawasan. Partisipasi menurut Mulyadi, (2016), Partisipasi adalah sesuatu yang mempunyai dampak masa depan bagi pembuat keputusan dan proses pengambilan keputusannya dilakukan secara bersama oleh dua pihak atau lebih. Partisipasi dalam penyusunan anggaran berarti keikutsertaan dua pihak atau lebih dalam pelaksanaan tanggung jawab manajemen didalam perencanaan, koordinasi dan pengawasan yang mempunyai dampak masa depan bagi pembuat keputusan.

\section{Sistem Pengendalian Intern Pemerintah}

PP No. 8 Tahun 2006 menjelaskan bahwa, sistem pengendalian intern diciptakan untuk memberikan keyakinan yang memadai untuk pencapaian efektivitas, efesiensi, ketaatan terhadap peraturan perundangundangan yang berlaku, dan keandalan penyajian laporan keuangan pemerintah melalui suatu proses yang dipengaruhi oleh manajamen. Unsur-unsur sistem pengendalian intern adalah lingkungan pengendalian, penilaian risiko, kegiatan pengendalian, informasi dan komunikasi, dan pemantauan.

\section{Komitmen Organisasi}

Komitmen organisasi menurut Robbins, (2008) ialah tingkat keyakinan terhadap seseorang karyawan dalam memihak pada organisasinya yang tujuannya memelihara keanggotaan dalam organisasi itu. (Meyer and Allens, 1997) menjelaskan bahwa terdapat tiga komponen model dari komitmen organisasi yaitu:
1. Affective commitment
pengertian
affective commitment

2. Continuance commitment pengertian continuance commitment

\section{Normative commitment}

\section{Kinerja Manajerial Sektor Publik}

Kinerja manajerial merupakan ilustrasi pencapaian terlaksananya suatu kegiatan atau program dalam mewujudkan sasaran, tujuan, visi dan misi pada organisasi. Secara garis besar, kinerja ialah prestasi yang dicapai oleh organisasi dalam periode waktu tertentu. Apabila tujuan dari anggaran tercapai itu artinya kinerja sudah berjalan efektif dan partisipasi dari bawahan memegang peranan penting dalam mencapai tujuan (Bastian, 2010). Indikator pengukuran kinerja manajerial menurut Mulyadi., (2016) terdiri atas, perencanaan, investigasi, koordinasi, evaluasi, supervisi, staffing, negosiasi, dan representasi.

\section{Hipotesis Penelitian}

Teori keagenan dan teori motivasi telah memberikan gambaran bahwasanya partisipasi anggaran akan mempengaruhi kinerja manajerial. Partisipasi penyusanan anggaran seharusnya akan menyebabkan kinerja manajerial menjadi lebih baik karena dengan adanya partisipasi penyusunan anggaran ini, individu dalam organisasi akan merasa memiliki tanggungjawab atas susunan anggaran. Pernyataan diatas didukung oleh penelitian-penelitian terdahulu yang dilakukan oleh Setiawan dan Rohani, (2019), Bumulo, et al., (2019), Brownell and Hirst, (1986), yang menyimpulkan bahwa partisipasi anggaran secara parsial berpengaruh positif terhadap kinerja manajerial.

Penjelasan diatas menyimpulkan bahwa hipotesis yang diajukan dalam penelitian ini adalah sebagai berikut :

H1 : Partisipasi anggaran berpengaruh terhadap kinerja manajerial

Selanjutnya teori keagenan menjelaskan bahwa sistem pengendalian intern juga dapat dikaji melalui teori keagenan yaitu melalui hubungan antara pengawas dan pihak yang diawasi. Tujuan utama dari sistem pengendalian intern menurut teori keagenan ialah tercapainya tujuan organisasi. Semakin handal sistem pengendalian intern maka akan semakin baik kinerja suatu organisasi dan makin mudahnya tercapai tujuan organisasi.

Hasil penelitian Kresnayana, et.al., (2020), Afrida, (2013), Candrakusuma dan Jatmiko (2017), menyatakan bahwa sistem pengendalian intern memiliki pengaruh positif terhadap kinerja manajerial. Penjelasan diatas menyimpulkan bahwa hipotesis yang diajukan dalam penelitian ini adalah sebagai berikut :

H2 : Sistem Pengendalian Intern berpengaruh terhadap kinerja manajerial.

Berikutnya goal setting theory adalah salah satu bagian dari teori motivasi yang menjelaskan bahwa seseorang akan bergerak jika memiliki tujuan yang jelas dan pasti.Komitmen organisasi ialah keinginan yang kuat dari dalam individu untuk melakukan sesuatu agar dapat mencapai keberhasilan organisasi sesuai dengan target dan mengesampingkan urusan pribadi dan mengutakan kepentingan organisasi. Penelitian yang dilakukan oleh Nugroho dan Sumiyanti, (2017), Putri, (2013), menyatakan bahwa komitmen organisasi sebagai variabel moderasi mampu menguatkan variabel partisipasi anggaran terhadap kinerja maanajerial. Penjelasan diatas menyimpulkan bahwa hipotesis yang diajukan dalam penelitian ini adalah sebagai berikut:

H3 : Komitmen organisasi dapat memoderasi hubungan antara partisipasi penyusunan anggaran dan kinerja manajerial 
Syindy Cantika, Mukhzarudfa dan Gandy Wahyu Maulana Zulma, Pengaruh Partisipasi Anggaran, dan Sistem Pengendalian Intern Pemerintah dengan Komitmen Organisasi Sebagai Variabel Moderasi Terhadap Kinerja Manajerial pada Organisasi Perangkat Daerah (OPD) Di Provinsi Jambi

Selanjutnya Latham and Locke, (2006) mengemukakan mengenai teori penetapan tujuan, yang menyimpulkan bahwa adanya keterkaitan antara tujuan dan kinerja seseorang terhadap tugas. Dukungan sistem pengendalian intern yang memadai, melatar belakangi tercapainya tujuan-tujuan dan sasaran-sasaran yang telah ditetapkan sebelumnya karena ditunjang oleh sumber daya manusia yang akan menggunakan kemampuannya untuk memper tanggungjawabkan keberhasilan atau kegagalan pelaksanaan tugas organisasi karena telah memiliki komitmen. Penelitian oleh Pertiwi dan Utami, (2020) menyimpulkan bahwa komitmen organisasi mampu memperkuat variabel sistem pengendalian internal terhadap kinerja manajerial. Penjelasan diatas menyimpulkan bahwa hipotesis yang diajukan dalam penelitian ini adalah sebagai berikut :

H4 : Komitmen organisasi dapat memoderasi hubungan antara sistem pengendalian intern dan kinerja manajerial.

\section{METODE}

Data primer dan data sekunder merupakan jenis data yang digunakan dalam penelitian ini, data primer diperoleh langsung dari sumbernya, dalam penelitian ini sumber data berasal dari hasil kuesioner yang telah disebarkan sedangkan data sekunder adalah data yang tidak diperoleh langsung dari sumbernya.

Populasi dalam penelitian ini ialah Organisasi Pemerintah Daerah (OPD) Provinsi Jambi, di Provinsi Jambi terdapat 43 Organisasi Perangkat Daerah baik itu dinas atau badan. Dalam penelitian ini peneliti memilih bagian pemerintahan urusan wajib yang berkaiatan dengan pelayanan dasar sebagai tempat penelitian, berjumlah lima OPD. Teknik pengambilan sampel pada penelitian ini menggunakan metode purposive sampling. Dalam penelitian ini kriteria yang dijadikan sampel yaitu

1. Middle-Low managers, dan

2. Pernah mengikuti penyusunan anggaran.

3. Bersedia meluangkan waktu untuk mengisi kuesioner.

Teknik pengumpulan data pada penelitian ini merupakan Cross section data, dalam penelitian ini data dikumpulkan dengan metode kuesioner (Mudrajad, 2003). Pengiriman kuesioner yang dibagikan secara langsung kepada pihak terkait di Organisasi Pemerintah Daerah (OPD) bagian pemerintahan urusan wajib yang berkaiatan dengan pelayanan dasar. Pengiriman kuesioner tersebut dilakukan sendiri oleh peneliti dengan tujuan agar tingkat pengembalian (responserate) kuesioner dapat lebih tinggi, sedangkan untuk pengambilan kuesioner yaitu dengan penetapan batas akhir tanggal pengambilan kuesioner.

Alat analisis yang digunakan adalah Moderated Regression Analysis (MRA) atau uji interaksi dengan menggunakan program Statistical Package for Social Science (SPSS). Adapun alasan penggunaan Moderated Regression Analysis (MRA) adalah karena penelitian ini menggunakan variabel moderasi. Untuk menganalisis jawaban kuesioner dari responden, diberi nilai dengan menggunakan ketentuan modifikasi skala Likert.

\section{HASIL DAN PEMBAHASAN Uji Validitas}

Penelitian ini menyatakan bahwa seluruh pernyataan pada kuesioner ini valid, karena $r$ hitung seluruh item pernyataan pada kuesioner dengan menggunakan uji Pearson (uji yang membandingkan $r$ hitung dengan $r$ tabel) lebih besar sama dengan $r$ tabel $(0,1857)$, dengan nilai korelasi terendah 0,447 .

\section{Uji reliabilitas}

Penelitian ini menghasilkan nilai cronbach alpha sebesar 0,896. Uji reliabilitas dinilai melalui besarnya koefisien alpha cronbach. Hasil uji reliabilitas instrument menunjukkan bahwa semua variabel memiliki koefisien alpha cronbach lebih besar dari 0,60. Jadi, dapat disimpulkan bahwa instrument partisipasi anggaran, sistem pengendalian intern, komitmen organisasi dan kinerja manajerial reliabel.

\section{Uji Asumsi Klasik}

$\begin{array}{crcr}\text { Hasil uji normalitas perhitungan } & \text { nilai } \\ \text { Kolmogorov-Smirnov dengan } & \text { signifikan } & 0,200 \text {. }\end{array}$ Berdasarkan hasil tersebut dapat dinyatakan data yang digunakan dalam penelitian ini telah berdistribusi normal dan bisa dilanjutkan untuk diteliti lebih lanjut, karena nilai signifikan dari uji normalitas > 0,05. Hasil uji multikolinearitas perhitungan nilai VIF untuk pengujian multikolinearitas antara sesama variabel bebas dapat dilihat pada sampel penelitian tidak ada yang melebihi 10 dan nilai tolerance tidak ada yang kurang dari 0,10 . Hal ini berarti bahwa hasil ini menunjukkan tidak adanya masalah multikolinearitas.Adapun hasil pengujian heterokedastisitas penelitian ini dapat dilihat tidak ada variabel yang signifikansi nya $<0,05$ sehingga dapat disimpulkan bahwa model regresi yang digunakan dalam penelitian ini terbebas dari heteroskedastisitas. 
Syindy Cantika, Mukhzarudfa dan Gandy Wahyu Maulana Zulma, Pengaruh Partisipasi Anggaran, dan Sistem Pengendalian Intern Pemerintah dengan Komitmen Organisasi Sebagai Variabel Moderasi Terhadap Kinerja Manajerial pada Organisasi Perangkat Daerah (OPD) Di Provinsi Jambi

Tabel 1. Uji Asumsi Klasik

\begin{tabular}{lcccc}
\hline \multicolumn{1}{c}{ Variabel Uji } & Signifikansi (sig.) & Tolerance & VIF & Keterangan \\
\hline Uji Normalitas & 0.200 & - & - & Normal \\
Uji Multikolinearitas & & & & Tidak ada masalah multikolinearitas \\
PA & - & 0.487 & 2.052 & \\
SPI & - & 0.165 & 6.050 & \\
KO & & 0.235 & 4.254 & Tidak terjadi homokedastisitas \\
Uji Heterokedastisitas & 0.096 & - & - & \\
PA & 0.090 & - & - & \\
SPI & 0.298 & - & - & \\
KO & & &
\end{tabular}

Sumber data: data diolah 2021

\section{Pengujian hipotesis}

Hipotesis satu diterima atau dapat disimpulkan bahwa partisipasi anggaran berpengaruh terhadap kinerja manajerial, hal ini dapat dilihat dari t hitung $>\mathrm{t}$ tabel yaitu 4,417> 1,98177 dan tingkat signifikansi $<0,05$ yaitu $0,00<0,05$. Hasil yang didapat sesuai dengan penelitian sebelumnya yang dilakukan oleh Setiawan dan Rohani, (2019), Bumulo, et al., (2019), dan Usman (2017) yang menyimpulkan bahwa partisipasi anggaran secara parsial berpengaruh positif terhadap kinerja manajerial. Temuan ini sejalan dengan teori motivasi dan teori keagenan yang menyatakan bahwa anggaran yang penyusunannya mengikutsertakan partisipasi para pelaksana dapat digunakan untuk memotivasi mereka dalam hal melaksanakan rencana, tujuan, dan sekaligus untuk mengukur prestasi mereka (Supriyono, 2004).

Mengakumulasikan dari beberapa penelitian yang juga membahas mengenai variabel ini dan mendapatkan hasi penelitian yang sama, untuk saat ini dan pada saat penelitian sebelumnya partisipasi anggaran mampu membuat atasan memiliki kesempatan untuk berinterksi, berkomunikasi dan memberi pengaruh terhadap tujuan dan sasaran yang ingin dicapai olah setiap lini dalam organisasi, sehingga hal itu memberikan dampak adanya keselarasan tujuan dari atasan dan bawahan sehingga nantinya tidak ada tuntutan karena adanya permasalahan di dalam anggaran dari pihak manapun karena keputusan di ambil secara bersama-sama. Fakta dilapangan menyatakan bahwa adanya partisipasi dalam penyusunan anggaran akan sangat baik untuk meningkatkan kinerja manajerial, oleh karena itu Organisasi Perangkat Daerah (OPD) khususnya di Provinsi Jambi sebaiknya menerapkan partisipasi berbagai lini dalam menyusun anggaran demi tercapainya kinerja manajerial yang baik. Saat setiap individu diberikan kesempatan untuk memiliki tanggungjawab maka individu tersebut akan terus berusaha memberikan upaya terbaik untuk mencapainya

Hipotesis dua diterima atau dapat disimpulkan bahwa sistem pengendalian intern berpengaruh terhadap kinerja manajerial, hal ini dapat dilihat dari $\mathrm{t}$ hitung $>\mathrm{t}$ tabel yaitu 7,608>1,98177 dan tingkat signifikansi < 0,05 yaitu $0,00<0,05$. Hasil yang didapat sesuai dengan penelitian sebelumnya yang dilakukan oleh Kresnayana, et .al (2020), Afrida (2013), Candrakusuma dan Jatmiko (2017) menyatakan bahwa sistem pengendalian intern memiliki pengaruh positif terhadap kinerja manajerial. Teori keagenan menjelaskan bahwa sistem pengendalian intern juga dapat dikaji melalui teori keagenan yaitu melalui hubungan antara pengawas (General Manajer) dan pihak yang diawasi (Manajer Operasional) ketat atau longgarnya sistem pengendalian tergantung pada kepercayaan pimpinan terhadap bawahannya.

Mengakumulasikan dari penelitian sebelumnya yang juga memiliki kesamaan dengan situasi saat ini bahwa tujuan dari pengendalian intern adalah untuk memberikan keyakinan memadai tentang pencapaian keandalan pelaporan keuangan, efektivitas dan efisiensi organisasi dan kepatuhan terhadap hukum dan peraturan perundangan-undangan yang berlaku maka apabila manajemen telah mampu melakukan hal ini dengan baik maka dengan sendirinya akan memberikan jaminan kepada manajemen untuk mencapai tujuan dan sasaran organisasinya. Fakta membuktikan bahwa adanya sistem pengendalian intern pemerintah akan sangat baik untuk meningkatkan kinerja manajerial, oleh karena itu Organisasi Perangkat Daerah (OPD) khususnya di Provinsi Jambi sebaiknya menerapkan sistem pengendalian intern pemerintah di dalam organisasi demi meningkatnya kinerja manajerial organisasi.

Hipotesis tiga ditolak atau komitmen organisasi tidak dapat memoderasi pengaruh partisipasi anggaran terhadap kinerja manajerial, karena tingkat signifikansi baik dari interaksi, maupun individual $>0,05$ dan $\mathrm{t}$ hitung pada interaksi dan individual $<\mathrm{t}$ tabel (1.98177). Hasil yang didapat sesuai dengan penelitian Hidayah dan Fauziah (2010), dan Mongeri (2013) yang menyatakan bahwa komitmen organisasi tidak signifikan dan tidak dapat memoderasi pengaruh partisipasi anggaran terhadap kinerja manajerial.

Temuan ini tidak sejalan dengan goal setting theory (teori penetapan tujuan) yang diangkat dalam penelitian ini. Dalam teori ini diasumsikan bahwa individu telah menentukan tujuan atas perilakunya di masa depan, dan tujuan tersebut akan mempengaruhi perilaku yang sesungguhnya. Dengan kata lain, teori ini menyatakan bahwa perilaku individu diatur oleh ide/pemikiran dan niat yang dimilikinya untuk mencapai 
Syindy Cantika, Mukhzarudfa dan Gandy Wahyu Maulana Zulma, Pengaruh Partisipasi Anggaran, dan Sistem Pengendalian Intern Pemerintah dengan Komitmen Organisasi Sebagai Variabel Moderasi Terhadap Kinerja Manajerial pada Organisasi Perangkat Daerah (OPD) Di Provinsi Jambi

tujuan/tingkat kinerja yang diharapkan. Temuan ini dapat disebabkan karena adanya penilaian dari diri anggota organisasi yang merasa bahwa tujuan dan nilainilai organisasi tidak sesuai dengan tujuan dan nilai-nilai pribadi yang ia miliki, dilibatkan dalam tanggungjawab mungkin mungkin membuat anggota akan bisa mengikutinya karena pada dasarnya itu sebuah kewajiban sebagai anggota organisasi, namun jika komitmen masih terdapat keberagaman kemauan atau pemikiran sehingga sulit untuk membuat individu anggota berkomitmen penuh terhadap organisasinya.

Hipotesis empat ditolak atau komitmen organisasi tidak dapat memoderasi pengaruh sistem pengendalian intern pemerintah terhadap kinerja manajerial, karena tingkat signifikansi baik dari interaksi, maupun individual $>0,05$ dan $\mathrm{t}$ hitung pada interaksi dan individual $<\mathrm{t}$ tabel (1.98177). Hasil yang didapat sesuai dengan penelitian Taufik, (2018) yang menyatakan bahwa komitmen organisasi tidak signifikan dan tidak dapat memoderasi sistem pengendalian intern pemerintah terhadap kinerja manajerial.

Hasil ini tidak sesuai dengan teori penetapan tujuan yaitu suatu model yang ditanamkan dalam individu yang digunakan untuk mendorong seseorang untuk memiliki tujuan, memilih tujuan, dan proses tersebut menjadi motivasi guna mencapai tujuan-tujuan tersebut. Karakteristik seseorang yang memiliki tujuan dalam teori ini ialah bahwa perilaku tersebut akan terus berlangsung hingga selesai dan tercapai. Apabila dalam diri seseorang mempunyai komitmen dalam pencapaian tujuan tertentu maka komitmen yang telah ditanamkan dalam diri seseorang tersebut akan mempengaruhi tindakannya.

Penelitian ini yang peneliti implementasikan dari penelitian sebelumnya, menjelaskan bahwa hasil penelitian ini tidak menggambarkan bahwa apabila seseorang memiliki tujuan maka seseorang tersebut akan terus melakukan tindakan menuju tujuan tersebut, peneliti menyimpulkan, hal ini terjadi diindikasi karena komitmen dari tiap individu yang belum kuat dalam menerapkan sistem pengendalian intern organisasi.

Masih adanya rasa individualis atau belum mempunyai rasa ingin tetap bertahan di dalam organisasi untuk waktu yang lama dari setiap individu. Disaat dihadapkan dengan peraturan mungkin anggota organisasi masih akan mentaatinya karena takut akan mempengaruhi organisasi secara global jika tidak diikuti, tetapi untuk menanamkan komitmen yang sama pada tiap individu merupakan suatu hal yang cukup sulit dilakukan. Berdasarkan hasil penelitian rata-rata hasil dari variabel ini memang menghasilkan nilai yang sangat kecil, karena dari tiap jawaban pernyataan individu sendiri masih dibayangi keraguan untuk berkomitmen di dalam organisasi. Di bawah ini tabel mengenai pengujian hipotesis:

Tabel 2. Uji hipotesisi

\begin{tabular}{|c|c|c|c|}
\hline \multirow[t]{2}{*}{ Variabel X } & \multicolumn{3}{|c|}{ Variabel Y (Kinerja Manajerial) } \\
\hline & T hitung & Signifikansi (sig.) & Keterangan \\
\hline PA (Partisipasi Anggaran) & 4.917 & 0.000 & Berpengaruh signifikan \\
\hline SPI (Sistem Pengendalian Intern Pemerintah) & 7.608 & 0.000 & Berpengaruh signifikan \\
\hline $\begin{array}{l}\text { KO X PA } \\
\text { (Komitmen Organisasi x Partisipasi Anggaran) }\end{array}$ & 0.359 & 0.720 & Tidak Berpengaruh Signifikan \\
\hline $\begin{array}{l}\text { KO X SPI (Komitmen Organisasi x Sistem } \\
\text { Pengendalian Intern Pemerintah) }\end{array}$ & -0.654 & 0.547 & Tidak berpengaruh signifikan \\
\hline R square & & & 0.612 \\
\hline Adjusted R square & & & 0.601 \\
\hline Jumlah sampel & & & 112 \\
\hline
\end{tabular}

Sumber data: data diolah 2021

\section{SIMPULAN}

Berdasarkan penelitian yang sudah dilakukan oleh peneliti, peneliti menetapkan kesimpulan dari penelitian ini adalah: Tingginya partisipasi anggaran berpengaruh terhadap kinerja manajerial. Sistem Pengendalian Intern Pemerintah yang diterapkan dengan baik maka akan menghasilkan peningkatan, dan hasil yang baik pula terhadap kinerja manajerial.Komitmen organisasi tidak mampu memoderasi pengaruh partisipasi anggaran terhadap kinerja manajerial.

Komitmen organisasi tidak mampu memoderasi pengaruh sistem pengedalian intern pemerintah terhadap kinerja manajerial.

\section{DAFTAR PUSTAKA}

Afrida, N., (2013). Pengaruh desentralisasi dan sistem pengendalian intern Pemerintah terhadap kinerja manajerial skpd (studi empiris pada pemerintah kota padang). Jurnal Akuntansi. Vol 1. No 2.

Bastian, Indra, (2010), Akuntansi Sektor Publik di Indonesia, Edisi 1, BPFE UGM, Yogyakarta

Brownell, P. and Hirst, M., (1986). Reliance on accounting information, budgetary participation, and task uncertainty: tests of a three-way interaction. Journal of accounting Research, pp.241-249.

Bumulo, R. A., Kalangi, L., \& Warongan, J. (2019). Pengaruh Partisipasi Penyusunan Anggaran 
Syindy Cantika, Mukhzarudfa dan Gandy Wahyu Maulana Zulma, Pengaruh Partisipasi Anggaran, dan Sistem Pengendalian Intern Pemerintah dengan Komitmen Organisasi Sebagai Variabel Moderasi Terhadap Kinerja Manajerial pada Organisasi Perangkat Daerah (OPD) Di Provinsi Jambi

terhadap Kinerja Manajerial dengan Motivasi, Komitmen Organisasi, dan Job relevant information (JRI) sebagai Variabel Moderating pada Perguruan Tinggi Swasta di Provinsi Gorontalo. JURNAL RISET AKUNTANSI DAN AUDITING" GOODWILL", 9(1).

Candrakusuma, D.A. and Jatmiko, B., (2017). Dampak komitmen organisasi, sistem pengendalian intern pemerintah, akuntabilitas publik, partisipasi anggaran dan kejelasan sasaran anggaran terhadap kinerja manajerial. Jurnal Bisnis dan Ekonomi, 24(1).

Harefa, K., (2008). Analisis Pengaruh Partisipasi Dalam Penyusunan Anggaran Terhadap Kinerja Manajerial Dengan Komunikasi Sebagai Variabel Moderating Pada PT. Bank Negara Indonesia, Tbk Di Medan (Master's thesis).

Fauziah, F. E., \& Hidayah, N. (2010). Pengaruh Partisipasi Anggaran Terhadap Kinerja Manajerial dengan Komitmen Organisasi sebagai Variabel Moderasi. Jurnal Dinamika Ekonomi dan Bisnis, 7(1), 57-79.

https://jambiprov.go.id/files/LKj Jambi 2019.pdf diakses pada 10 januari 2021

Jannah, M., \& Rahayu, S. (2015). Pengaruh Partisipasi Penganggaran terhadap Kinerja Manajerial SKPD dengan Kejelasan Sasaran Anggaran, Komitmen Tujuan Anggaran, Keadilan Distributif dan Pengawasan Internal sebagai Variabel Intervening. Jurnal Perspektif Pembiayaan dan Pembangunan Daerah, 3(2), 69-90.

Kresnayana, I.G.A.B., Putra, I.G.C. and Sunarwijaya, I.K., (2020). Sistem Pengendalian Intern, Locus Of Control, Partisipasi Anggaran, Dan Kinerja Lembaga Perkreditan Desa. Kumpulan Hasil Riset Mahasiswa Akuntansi (KHARISMA), 2(2), pp.188-208.

Locke, E.A. and Latham, G.P., (2006). A theory of goal setting \& task performance. Prentice-Hall, Inc.

Medina,F., (2012). Faktor-Faktor yang Mempengaruhi Transparansi Informasi Keuangan Pada Situs Resmi Pemerintah Daerah. Skripsi. Universitas Diponegoro Semarang.

Meyer, J. P., \& Allen, N. J. (1997). Commitment in the workplace: Theory, research, and application. Sage.

Mongeri, M., (2012). Pengaruh Partisipasi Penyusunan Anggaran terhadap Kinerja Pemerintah Daerah dengan Komitmen Organisasi sebagai Moderating (Studi Empiris pada SKPD Pemerintah Kota Padang). FE Universitas Negeri Padang.

Mowday, R. T., Porter, L. W., \& Steers, R. (1982). Organizational linkages: The psychology of commitment, absenteeism, and turnover.

Mulyadi, (2016). Sistem Akuntansi. Edisi 4, Jakarta: Salemba Empat.
Mudrajad, K., (2003). Metode riset untuk bisnis dan ekonomi. Jakarta: Erlangga.

Nafarin, M, (2004), Penganggaran Perusahaan, Salemba Empat, Jakarta.

Nugroho, P. S., \& Sumiyanti, T. (2017). Pengaruh Partisipasi Anggaran, Kejelasan Sasaran Anggaran terhadap Kinerja Manajerial dengan Komitmen Organisasi dan Politik Organisasi sebagai Variabel Moderasi. Jurnal Ilmu Manajemen dan Akuntansi Terapan (JIMAT), 8(2), 104-118.

Peraturan Pemerintah No.8 Tahun 2006

Pertiwi, R. U., \& Utami, E. R. (2020). Pengaruh sistem pengendalian intern dan ketaatan pada peraturan perundangan dengan komitmen organisasi sebagai variabel moderasi. In Proceeding of National Conference on Accounting \& Finance (Vol. 2, pp. 98-118).

Putri, G.Y., (2013). Pengaruh Komitmen Organisasi Dan Sistem Pengendalian Intren Pemerintah (SPIP) Terhadap Kinerja Manajerial SKPD (Studi Empiris pada Satuan Kerja Perangkat Daerah Kota Padang). Jurnal Akuntansi, 1(1).

Robbins, S. (2008). Perilaku Organisasi, Jilid I dan II, alih Bahasa: Hadyana Pujaatmaja. Jakarta: Prenhallindo.

Setiawan, D. and Rohani, R., (2019). Pengaruh Partisipasi Anggaran Dan Akuntansi Pertanggungjawaban Terhadap Kinerja Manajerial (Studi Kasus Pada PT. Indonesia Power Unit Pembangkit dan Jasa Pembangkit Kamojang). AKURAT $\mid$ Jurnal Ilmiah Akuntansi FE UNIBBA, 10(1), pp.57-73.

Sumarno, S., (2006). Pengaruh Sistem Pengendalian Terhadap Kinerja Manajerial (Studi Kasus pada Perusahaan Pelayaran di Semarang) (Doctoral dissertation, program Pascasarjana Universitas Diponegoro).

Supriyono, R. S. (2004). Pengaruh variabel intervening kecukupan anggaran dan komitmen organisasi terhadap hubungan antara partisipasi penganggaran dan kinerja manajer di Indonesia. Journal of Indonesian Economy and Business, 19(3).

Taufik, H. (2018). Pengaruh Sistem Pengendalian Internal Pemerintah Terhadap Kinerja Manajerial Dengan Komitmen Organisasi Sebagai Pemoderasi: Studi Empiris pada Satuan Kerja Perangkat Daerah di Kabupaten Sumedang (Doctoral dissertation, Universitas Pendidikan Indonesia).

Triana, M., Yuliusman dan Wirmie Eka Putra, (2012). Pengaruh Partisipasi Anggaran, Budget Emphasis, dan Locus of Control Terhadap Slack Anggaran (Survei pada Hotel Berbintang di Kota 
Syindy Cantika, Mukhzarudfa dan Gandy Wahyu Maulana Zulma, Pengaruh Partisipasi Anggaran, dan Sistem Pengendalian Intern Pemerintah dengan Komitmen Organisasi Sebagai Variabel Moderasi Terhadap Kinerja Manajerial pada Organisasi Perangkat Daerah (OPD) Di Provinsi Jambi

Jambi). E-jurnal Binar Akuntansi (Vol) ISSN, pp.2303-1522.

Undang-undang Nomor 32 Tahun 2004 tentang Pemerintah Daerah

Undang-undang Nomor 33 Tahun 2004 tentang Perimbangan Keuangan Pusat dan Daerah

Usman, A., (2017). Participation, goal clarity budget to performance apparatus with environmental uncertainty and individual culture as a moderating variables. The Business \& Management Review, 9(2), pp.59-66. 